command of the Tank Corps First Brigade. Shaw was one of the very few civilians allowed to view the tank depot.

It was my great pleasure and privilege to give GBS his first, and probably his last, ride in a tank.

With boy-like glee he watched the machines ascending and descending steep banks, going over their 'jumps', and generally being put through their paces. He eagerly accepted my invitation to be a passenger and he sat on the improvised seat with a smile of perfect happiness on his face, while the tank jolted and bumped over the hard, uneven ground. After the ride was finished, he descended and was, with some difficulty, discouraged from pressing a Treasury note on the driver of the tank.

\title{
At the Front 1917: IV
}

\section{DOUGLAS HAIG}

From The Private Papers of Douglas Haig 1914-1919, ed. Robert Blake (London: Eyre \& Spottiswoode, 1952) pp. 194-5. Field-Marshal Sir Douglas (later Earl) Haig (1861-1928) was British Commander-in-Chief on the Western Front from December 1915 until the end of the war. His note of Shaw's visit is dated 1 February.

Mr Bernard Shaw (the Author and Playwriter) came to lunch. An interesting man of original views. A great talker! On sitting down to lunch, I at once discovered he was a vegetarian. As if by magic, on my ordering it, two poached eggs appeared, also some spinach and also macaroni, so he did not fare badly.

\section{At the Front 1917: V}

\section{DAVID POWELL(?)}

From Winifred Loraine, Robert Loraine: Soldier, Actor, Airman (London: Collins, 1938) p. 237. When he reached Loraine's airfield, Shaw found two of his short wartime plays in production ( $O^{\prime}$ Flaherty $V C$ still awaited a public performance). 